УДК 159.95

DOI: https://doi.org/10.33120/popp-Vol24-Year2021-66

Ольга Палагнюк

кандидат психологічних наук, докторант, Інститут соціальної та політичної психології НАПН України, м. Київ, Україна

ORCID ID 0000-0002-1152-2133

o.palahnyuk@chnu.edu.ua

\title{
СОЩАЛЬНА СОЛІДАРНІСТЬ У КОНТЕКСТІ ПОШУКУ ШЛЯХІВ ДОСЯГНЕННЯ І ЗБЕРЕЖЕННЯ ЦІЛІСНОСТІ СУСПІЛЬСТВА: МІЖДИСЦИПЛІНАРНИЙ АНАЛІЗ
}

Актуальність статті визначається необхідністю поглиблення соціально-

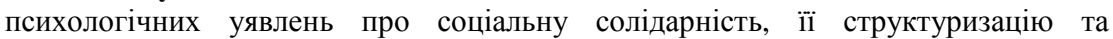
особливості функціонування в умовах суцільних диференціацій, дезінтеграцій $\mathrm{i}$ конфліктів та пошуку шляхів досягнення й збереження цілісності суспільства.

Метою статті $\epsilon$ вивчення структуризації соціальної солідарності 3 акцентуванням уваги на сучасних підходах, що розробляються в межах соціальної психології в умовах поглиблення соціальної диференціації і трансформаційних змін українського суспільства.

Методологія та наукові підходи: метатеоретична концепція діалогічної форми солідарності (Габермас, 2000); положення теорії соціального порівняння, згідно 3 яким утворення великих соціальних груп $є$ основою ідентифікації як оцінювання їхніми членами точності своїх особистих переконань і поглядів (Фестингер, 1999); положення про соціальні трансформації, які є «наскрізною рамкою аналізу» (Богомолова, 2002); положення про тотальну індивідуалізацію життя, становлення здатного до рефлексії суб'єкта (Бек, 2000); визначення спільнот як особистих мереж, які більше не обмежуються географічними районами i мають можливість надавати різні види підтримки як прояви солідарності (Wellman, \& Wortley, 1990).

Результати. Визначено, що соціальна солідарність - це специфічна властивість суспільства, що виникає стихійно або керовано на основі інтеграції особистісних потенціалів солідарності більшості його членів, завдяки чому відбувається конвергенція суспільних процесів на спільній меті та формується згуртованість на рівні великих груп. Встановлено, що солідарність як згуртованість великих груп уможливлює ефективне розв'язання проблем та досягнення цілей сталого розвитку; що є потреба в новому погляді на поняття i механізми солідарності, пов'язана 3 тим, що багато феноменів сучасних солідаризаційних процесів неможливо пояснити тільки на засадах класичних теорій солідарності. Поняття «нова солідарність» визначено як загальноприйняте, 
що втрачає територіальну, класову за ангажованість і більше не відтворює постійну спільність інтересів, цінностей.

Висновки. Психологічне структурування соціальної солідарності уможливлює розмежування iii особливостей у різних соціальних вимірах. Акцентування уваги на соціальній взаємодії, комунікації, ролі довіри, соціальної відповідальності і толерантності в процесах солідаризації розкриває специфіку різновекторної площини досягнення i збереження соціальної солідарності. Особистість формує своє усвідомлене ставлення до певних перспектив суспільного життя, психологічним осередком якого $є$ «особистісний потенціал солідарності». Солідарність як згуртованість великих соціальних груп досягається за рахунок дії певних механізмів, зокрема переживання співпричетності, полілогу спільнот, висхідної і низхідної ініціатив та динамічного балансу процесів конкурування і кооперування спільнот.

Ключові слова: соціальна солідарність; особистісний потенціал солідарності; виміри соціальної солідарності; механізми досягнення i підтримання солідарності; цілісність суспільства.

\section{Olha Palahnyuk}

$\mathrm{PhD}$ in Psychology, Doctoral student of the Institute

of Social and Political Psychology

of the NAES of Ukraine,

Kyiv, Ukraine

ORCID ID 0000-0002-1152-2133

o.palahnyuk@chnu.edu.ua

\section{SOCIAL SOLIDARITY IN THE CONTEXT OF SEARCHING WAYS TO ACHIEVE AND PRESERVE THE INTEGRITY OF SOCIETY: INTERDISCIPLINARY ANALYSIS}

The relevance of scientific researchis determined by the need to deepen sociopsychological ideas about social solidarity, its structuring and features of functioning in conditions of continuous differentiation, disintegration and conflict and finding ways to achieve and preserve the integrity of society.

The purpose of the research is to study the structuring of social solidarity with an emphasis on modern approaches and prospects for its development within social psychology in the context of deepening social differentiation and transformational changes in Ukrainian society.

Methodology and scientific approaches: metatheoretical concept of dialogical form of solidarity (Habermas, 2000); provisions of the theory of social comparison, according to which the formation of large social groups is the basis of identification as an assessment by their members of the accuracy of their personal beliefs and views (Festinger, 1999); provisions on social transformations, which act as a «cross-cutting framework of analysis» (Bogomolova, 2002); provisions on the total individualization of life, the formation of a reflective subject (Beck, 2000); defining communities as 
personal networks that are no longer limited to geographical areas and have the ability to provide various types of support that are manifestations of solidarity (Wellman, \& Wortley, 1990).

The main results. It is determined that social solidarity is a specific property of society that arises spontaneously or managed on the basis of integration of personal potentials of solidarity of the majority of its members, due to which there is a convergence of social processes on a common goal and cohesion at large groups. It is established that solidarity as a cohesion of large groups enables effective problem solving and achievement of sustainable development goals; that there is a need for a new look at the concepts and mechanisms of solidarity is due to the fact that many phenomena of modern solidarity processes today can not be explained solely on the basis of classical theories of solidarity.It is generally accepted that the concept of «new solidarity» is lost, which loses territorial, class involvement, ceases to reproduce the constant commonality of interests and values.

Conclusions. Psychological structuring of social solidarity makes it possible to distinguish its features on different social dimensions. Emphasis on social interaction, communication, the role of trust, social responsibility and tolerance in the processes of solidarity reveals the specifics of the multi-vector plane of achieving and maintaining social solidarity. The individual forms his conscious attitude to certain prospects of social life, the psychological center of which is the «personal potential of solidarity."Solidarity as a cohesion of large social groups is achieved through mechanisms such as the experience of participation, the polylogue of communities, upward and downward initiatives and the dynamic balance of processes of competition and cooperation of communities.

Keywords: social solidarity; personal potential of solidarity; dimensions of social solidarity; mechanisms for achieving and maintaining solidarity; integrity of society.

Постановка проблеми. Психологічний підтекст суспільних перетворень за останні десятиріччя все більше спонукає науковців різних напрямків наново звернути дослідницьку увагу на проблему цілісності, єдності суспільства, що потерпає від суцільних диференціацій, дезінтеграцій, конфліктів, а подекуди, навпаки, від глобалізаційних процесів, що стирають закріплені досі межі i кордони, формуючи множинність ідентифікацій та об'єднання на абсолютно нових засадах. Відбувається кардинальне перетворення усіх сфер соціуму.

Сучасне українське суспільство характеризується багатьма диференціаціями - соціокультурними, політико-ідеологічними, етнонаціональними, мовними, регіональними, конфесійними та іншими, які $є$ підгрунтям різних ідентичностей. Тому гостро постає проблема збереження цілісності, пошук консолідаційних чинників, що є одним із домінантних напрямів дослідження суспільних наук, зокрема соціальної та політичної психології. Зрештою, це спрямовує до осмислення соціальної солідарності в розрізі психології, зважаючи на невиробленість 
відповідної цілісної соціально-психологічної теорії, фрагментованості підходів до ії розуміння, у численних теоретичних суперечностях, що створюють неінтегративне i дискретне поле емпіричних даних, незбалансованість психологічного, соціального, політичного, правового вимірів представлення феномену в наукових дискурсах.

Солідаризаційні процеси сучасного соціуму характеризуються все більшою всеохопністю та всюдипроникністю внаслідок безперервної появи все нових і нових соціальних груп різного масштабу. Сьогодні світові глобалізаційні процеси, безперечно, впливають і на особливості солідаризації, яка набуває змістової трансформації.

Аналіз останніх досліджень i публікацій. Теоретичним підгрунтям дослідження соціальної солідарності є насамперед класичні і сучасні концепції соціальної солідарності в межах різних наукових галузей. Найближча до такого розуміння , зокрема, метатеоретична концепція діалогічної форми солідарності Ю. Габермаса (2000), який розглядає соціальну солідарність як результат консенсусу між громадянами, що досягається за допомогою соціального діалогу. Зокрема, дослідник трактує солідарність як основу дії, спрямованої на взаєморозуміння. Солідарність символічно структурує життєвий світ, який породжується інтерсуб'єктивними відносинами і соціальними процесами, метою яких є діалог і досягнення згоди. Таким чином, солідарність завжди передбачає кон'юктивацію, сурядність, що досить важливо для збереження цілісності й соціальної структури. Засадничим також стає осмислення масових явищ психіки, зумовлених належністю індивіда до великої соціальної групи (Г. Теджфел); положення теорії соціального порівняння, згідно з яким утворення великих соціальних груп $є$ основою ідентифікації як оцінювання їхніми членами точності своїх особистих переконань і поглядів (Фестингер, 1999); положення про соціальні трансформації, які є «наскрізною рамкою аналізу» (Богомолова, 2002).

Однак на відміну від попередніх епох, сучасні глобалізаційні, модернізаційні процеси демонструють втрату важливості територіальних, класових детермінант під час формування та реалізації соціальних процесів у сучасному суспільстві. Відбувається тотальна індивідуалізація життя, становлення здатного до рефлексії суб'єкта (Бек, 2000). Сучасна людина володіє можливістю вибору спрямованості власного руху із широкого спектра можливостей. Можна обирати соціальну групу, субкультуру з огляду на свою ідентифікацію. Звідси як результат утвердження «клаптикової ідентичності», основною рисою якої $є$ відмова від традиційної відповідальності. Тож ідеться про сполучення непоєднуваних елементів (Урри, 2012). 
Виокремлюючи дослідницькі результати щодо вимірів, видів, критеріїв та механізмів соціальної солідарності, доцільно брати до уваги те, що сучасні зарубіжні й українські науковці зосереджені на різних аспектах та різних рівнях цього явища: від солідарності малих груп і до соціальної солідарності суспільства й людства загалом, де цей феномен розглядається як одна 3 передумов стабільності й соціального порядку. Психологи також цікавляться явищем соціальної солідарності в різноманітті його проявів не тільки в теоретичному ракурсі, а й з метою застосування концепту солідарності в емпіричних дослідженнях для пояснення людської поведінки. Водночас частина дослідників наголошує на таких ознаках, як кооперація, згуртованість, єдність, інші як основні ознаки виокремлюють довіру, наявність спільних ідей, поглядів, цілей, треті - належність до певного цілого і відповідну самоідентифікацію, четверті пропонують інші варіанти конструктів соціальної солідарності, поєднуючи ці характеристики в різні комбінації або додаючи свої. Так, Веллман і Вортлі пропонують визначення спільнот як особистих мереж, які більше не обмежуються географічними районами і мають можливість надавати різні види підтримки (Wellman, \& Wortley, 1990), що є проявами солідарності. До того ж сучасні визначення соціальної солідарності не охоплюють множинності цінностей і культур, які побутують у нинішніх суспільствах, i, як наслідок, теперішні суспільства можуть керуватися та формуватися навколо конструкції, яка також може призводити до істотного/хронічного конфлікту.

В українській соціальній психології питання соціальної солідарності розглядають у контексті проблеми суспільної консолідації, інтеграції, згуртованості українського суспільства на основі пошуку спільних ідей об’єднання Заходу і Сходу, подолання соціальної напруженості, визначення векторів євроінтеграційних процесів. Аналіз останніх публікацій свідчить про інтенсивне міждисциплінарне розроблення понять: «соціальна єдність», «консолідація» i «солідарність», які в межах різних методологічних традицій (соціологія, психологія, політологія, культурологія, філософська антропологія, соціальна філософія, релігієзнавство) здебільшого вживаються як взаємозамінні. У межах же соціальної психології мають місце численні розвідки, релевантні щодо проблематики соціальної солідарності, які стосуються розгляду: проблем національної й соціальної ідентичності (становлення політико-правової свідомості молоді (Сіверс, Духневич, Осадько, 2017); соціально-психологічних властивостей спільноти в перспективі її розвитку (Васютинський, 2010); націєтворення: суб'єктних вимірів націєтворення (Татенко, 2020), суспільної (національної) консолідації в межах націєтворення (Суший, 2018); порядку соціальності 
та його психологічних детермінант: норм, звичок, традицій, настановлень (Титаренко; Кочубейник, \& Черемних, 2014); чинників, видів та механізмів суспільної консолідації (Овчаров, 2011); психології груп і психологічної підтримки суспільних трансформацій в межах рольової взаємодії, детермінованої закономірністю рольової комплементарності (Слюсаревський, Найдьонова, Титаренко та ін., 2020); особливостей солідаризації в професійних відносинах в умовах сучасних суспільних викликів: реформ, економічних криз, політичнихсуперечностей, воєнних конфліктів (Лобанова, \& Коломієць, 2016).

Отже, досі немає цілісної наукової психологічної теорії соціальної солідарності, а тому і соціально-психологічного аналізу ії структуризації. Співіснування та змішування різних трактувань солідарності призвело до значної строкатості ii соціальних репрезентацій (релігійна чеснота, моральний обов'язок, політичне гасло, елемент державної політики, соціальних і благодійних рухів) та наукових дефініцій у межах різних наукових напрямів (фізичний, хімічний, біологічний, соціальний, економічний, юридичний) (Гофман, 2019). Саме тому ми намагалися спитатися на історію дослідження соціальної солідарності на соціальнопсихологічному рівні, iї структуризації та виокремлення механізмів 3 акцентом на сучасних підходах в умовах поглиблення соціальної диференціації і трансформаційних змін соціуму.

Мета наукового дослідження - вивчення соціальної солідарності з акцентуванням уваги на сучасних підходах, що розробляються в межах соціальної психології в умовах поглиблення соціальної диференціації і трансформаційних змін українського суспільства.

Виклад основного матеріалу дослідження. Яким би не було його історичне походження, поняття «солідарність» має особливий резонанс із потребами нашого часу. Для багатьох воно $є$ моральним і політичним принципом, який протистоїть індивідуалізму, атомізму та фрагментації людського життя, які сукупно сприймаються як недоліки, пов'язані 3 класичною ліберальною культурою. Солідарність у низці дефінітивних значень відносять сьогодні до різнорівневих соціальних зв'язків, використовуючи для опису та визначення природної соціальної інтеграції (єдності) на противагу хаосу і конфлікту або штучній солідарності, заснованій на примусі чи максимізації чиїхось приватних інтересів. Це поняття можуть використовувати також для позначення революційних громадських рухів, спрямованих проти панівної несправедливості, поєднуючи в єдине ціле невеликі громади, військові або ж політичні рухи, суспільство чи навіть людство загалом. Солідарність іноді тлумачать у широкому сенсі - як позначення базової етичної турботи про 
інших, просоціальних думок та вчинків (Рорти, 1996). У цьому контексті iii часто називають моральною, або людською, солідарністю.

Узагальнення представлених у наукових дискурсах дефініцій та визначень солідарності та їх інтерпретація в контексті сучасних суспільних умов життя стали основою авторського трактування досліджуваного феномену в межах соціальної психології. Зокрема, ми тлумачимо сочіальну солідарність як специфічну властивість суспільства, що виникає стихійно або керовано на основі інтеграції особистісних потенціалів солідарності більшості його членів, завдяки чому відбувається конвергенція суспільних процесів (соціальних, політичних, психологічних, освітніх, інформаційних тощо) на спільній меті та формується згуртованість на рівні великих груп. Солідарність як згуртованість великих груп уможливлює ефективне розв'язання проблем та досягнення цілей сталого розвитку. Потреба в новому погляді на поняття і механізми солідарності пов'язана з тим, що багато феноменів сучасних солідаризаційних процесів неможливо пояснити виключно на засадах класичних теорій солідарності. Сьогодні неможливо говорити про універсальний феномен солідарності в сучасному житті. Для нинішнього процесу характерне співіснування традиційних форм солідарності, описаних у класичній науковій традиції, і поява новітніх сучасних форм, пов'язаних 3 кардинальною зміною соціального середовища у світі, появою новітніх ІКТ.

Особливий відбиток на солідаризаційні процеси в українському суспільстві накладає ситуація нестабільності. Солідаризаційні процеси сьогодні пов' язуються з такими феноменами сучасності, як «рефлексивна модернізація», «індивідуалізація», «функціональна диференціація», «глобалізований індивідуалізм», «клаптикова ідентичність», «дія на відстані», які намагаються пояснити сучасні глобалізаційні процеси і $\epsilon$ характерними для теоретичного викладу постмодерністських концепцій (Бауман, 2002; Бек, 2000; Гидденс, 2004; Урри, 2012; Филиппов, 2008).

Сьогодні відбувається відхід від класичних трактувань поняття солідарності, набуває чинності поняття «нова солідарність», трактування якого ми теж певною мірою поділяємо. Цей підхід базується на тому, що сучасна солідарність втрачає територіальну, класову заангажованість, уже не відтворює, як досі, постійну спільність інтересів, цінностей. Проте відносне структурування соціальної солідарності все ж таки уможливлює розмежування іiі психологічних особливостей на вимірах від особистісного до цивілізаційного, а також на векторах іiі досягнення (вертикальна, горизонтальна й діагональна соціальна солідарність).

Так, особистість (мікрорівень солідарності), як член певної сукупності великих груп, одночасно перебуває на перетині багатьох 
впливів, унаслідок чого формує своє усвідомлене ставлення до тих чи інших перспектив суспільного життя. Психологічним осередком такого ставлення ми пропонуємо вважати «особистісний потенціал солідарності», тобто якісну характеристику особистісної спроможності діяти вільно, активно та усвідомлено в напрямі суб'єктно сформованої (сконструйованої певним дискурсом) ціннісно-ідеологічної смислової системи. У певному сенсі про особистісний потенціал солідарності може йтися як про систему індивідуальних відмінностей, пов'язану 3 інтенціями на згуртованість навколо певних смислів, цілей та цінностей.

К. Ларсен наводить доречну аргументацію про глобалізований мультикультуралізм і про те, як він може суперечити ідеї подібності розуму і спільних цінностей, необхідних для встановлення довіри (i солідарності більшою мірою) (Larsen, 2013). Він стверджує, що гетерогенність суспільства і вся його різноманітність суперечить соціальній солідарності, оскільки солідарне суспільство має моральний компас (заснований на довірі). Це означає, що не може бути загальної довіри між різними групами людей з різними культурами і цінностями. Нездатність досягти визнання всіх форм людського роду та їхніх різноманітних проявів веде 3 часом до фрагментарної і негативної солідарності (Cheong et al., 2007). А проте змішані територіальні громади, суспільства - це краще, ніж відокремлені кластери високозгуртованих спільнот (негативна солідарність), оскільки вони пропонують більш відкриту взаємодію, яскраву опозицію та досягають балансу між культурною автономією і соціальною солідарністю (Amin, 2002; Cheong et al., 2007). Аргумент щодо необхідності оновленого визначення солідарності походить від необхідності створити більш зрілі стійкі суспільства (Sellberg, Wilkinson, \& Peterson, 2015), які враховують мультикультурний компонент і потребу в постійній ідентифікації. Останне пов'язане з безперервним процесом розвитку добробуту, почуття причетності та добровільної соціальної участі членів суспільства, з розвитком спільнот, які толерують і пропагують різноманітність цінностей і культур і водночас надають рівні права та можливості в суспільстві.

Британський дослідник Дж. Урі, зосереджуючись на тому, «як розвиток різних глобальних «мереж і потоків» підриває ендогенні соціальні структури, які мають здатність відтворювати самих себе», визначає мобільність як основну характеристику сучасного суспільства (Урри, 2012). Він говорить про мобільну (рухливу) солідарність як особливість сучасної солідаризації. Водночас наголошує, що така солідарність, на відміну від солідарності територіальної, притаманна лише відносно невеликим групам, кожен із членів якої не має зобов'язань перед іншими і має досить слабкі зв'язки з їі членами (Urry, 2012). 
Окреслюючи специфіку сучасної солідаризації, О. Філіппов (2008) зазначає, що «нова солідарність» - це «ситуативний феномен», який 3'являється в організації певних соціальних подій.

Сьогодні для того, щоб вивчати феномен солідаризації, потрібно відмовитися від традиційних територіальних, державних кордонів солідарності. У сучасному світі з'являються нові форми мобільності, пов'язані зі зміною засобів комунікації, появою новітніх технологічних засобів, зміною уявлень про сприйняття часу і простору. Усе це сприяє формуванню нових мобільних солідарностей (Филиппов, 2008). Дослідження феномену нової солідарності пов'язується сьогодні 3 поняттями мобільності i соціальної події. Таке розуміння надає можливість досліджувати солідаризацію людей, не об'єднаних певною територією. Механізм такої дії можна пов'язати 3 «функціональною диференціацією» суспільства, про яку говорить Х. Брункхорст (2005), зазначаючи, що «сьогодні, на початку XXI ст., в усіх країнах формат глобального суспільства задає функціональна диференціація. Винайдене на Заході функціонально диференційоване суспільство глобалізувалося, перетворилося на одне суспільство, приведене до руху революціями, які відбулися в засобах поширення [інформації] і техніці перевезень. Воно було європейським проєктом, проте тепер воно перетворюється на глобальне суспільство, яке втрачає всілякі локально привілейовані позиції і стає абсолютно децентрованим» (Brunkhorst, 2005, p. 111). Тобто над нормами і правилами лояльності спільнот надбудовувалися більш загальні, абстрактні норми та цінності суспільства держави (Филиппов, 2008).

Отже, солідаризація набуває характеристик різновимірності (від цивілізаційного до міжособистісного), які тісно взаємопов'язані 3 інтенсивністю, типами, механізмами зв'язків між соціальними суб'єктами, характером і способом комунікації, особливостями ідентифікаційних процесів, що відкриває нові горизонти соціально-психологічних досліджень. До прикладу, серед нових підходів до трактування солідарності можна виділити також пропозицію відмовитися від солідарності як загального терміна і натомість використовувати його як у вузькому, так і в транснаціональному сенсі. Адже змінюється природа соціальних зв'язків. Солідарність передбачає турботу про благополуччя інших (Savulescu, 2018; Davies, \& Savulescu, 2019) і розуміння того, що людина може максимізувати своє благополуччя, покращуючи умови для інших (Stjerno, 2004; Wilde, 2007). Це досить яскраво проявляється в часи всесвітньої боротьби з пандемією, спричиненою COVID-19, коли суспільство має боротися із синдромами соціальної дистанції, відчуження та індивідуалізму. Щоб подолати цю кризу, потрібно розвивати колективну свідомість. Соціальна солідарність може мотивувати людей 
дотримуватися соціального дистанціювання, ізолювати пацієнтів і стигматизованих від психічних травм, знизити рівень зараження i сприяти збереженню здоров'я. Поширення фізичних запобіжних заходів за допомогою колективних зусиль і колективного співпереживання може допомогти налагодити добробут максимальної кількості людей. У соціальній кризі соціальна солідарність $є$ потужною відповіддю на поглинання шоку. Соціальне дистанціювання має поєднуватися із соціальною солідарністю, щоб бути ефективним інструментом для стримування наслідків пандемії. Інститути, окремі особи та спільноти відіграють незамінну роль як доцентрова сила суспільства, щоб протистояти відцентровій тенденції нового коронавірусу. Це залежить від нас і від внеску наших спільних зусиль у пул солідарності в подоланні цієї катастрофи.

Акцентуючи увагу на соціальній взаємодії, комунікації, ролі довіри, соціальної відповідальності і толерантності в процесах солідаризації, важливим для нас $\epsilon$ локус дослідницької уваги на специфіці різновекторної площини тї здійснення (вертикальної: взаємодія влади й народу i навпаки; горизонтальної: взаємодія різних за спрямуванням і належністю соціальних груп; діагональної: здебільшого неформальна взаємодія між учасниками одного процесу, які не перебувають у формальних відносинах); спрямованості впливу під час взаємодії (згори вниз і навпаки або ж горизонтально). Слабкі зв'язки в будь-якому із цих вимірів можуть створювати проблеми. Слабка горизонтальна солідарність часто призводить до конфлікту, тоді як результатом слабкої вертикальної солідарності нерідко стає брак довіри між владою і рештою суспільства.

У контексті пошуку способів і шляхів досягнення суспільної цілісності, єдності на основі солідаризації важливо сфокусувати дослідницьку увагу на механізмах ії досягнення та підтримання. Стійка система взаємодій великих соціальних груп різних типів і рівнів, що сприяє виробленню спільноподілюваної мети (перспектив і векторів суспільного руху) і $є$ таким соціальним механізмом(-ми). Їх функціонування регулюється, з одного боку, відповідними громадськими інститутами (формальними і неформальними правилами гри), а 3 другого - соціальним статусом та особливостями великих груп. Основна особливість соціальних механізмів полягає в їхній здатності регулювати процеси досягнення й підтримання солідарності. Ця здатність пояснюється особливою значущістю, силою і стійкістю тих соціальних зв'язків, які зумовлюють їхню системність. Оскільки в механізмах соціальних процесів співіснують елементи, що виникли в минулому або сформовані в теперішньому, ці механізми відрізняються високою 
інерційністю і їхнє оновлення завжди є лише частковим. Крім того, у них співіснують феномени і цілеспрямовано створювані для досягнення певних цілей, і ті, що виникають стихійним або природно-історичним шляхом. Перші конституюються в процесі соціальних перетворень, другі виникають спонтанно в процесі суспільної еволюції і змінюються під впливом внутрішніх трансформацій.

3 огляду на вертикальну спрямованість соціальної солідарності важливо зосередити увагу на висхідній і низхідній ініціативах, які остаточно уможливлюють функціонування досліджуваного феномену як одного з їі механізмів. Соціальна солідарність як феномен, пов'язаний 3 площиною об'єктивних законів функціонування соціального як такого, завжди має місце в житті соціуму і завжди, як уже зазначалось, це зв' язки кон'юктивні, об'єднувальні. Беручи до уваги різновекторність таких взаємодій у контексті проявів соціальної відповідальності, яка, власне, $є$ також компонентою суб'єктності, значущості набуває прояв ініціативи (соціальної). У суспільстві, де панують демократичні відносини, переважають солідаризовані групи, прийнятними $\epsilon$ свобода слова i волевиявлення в межах громадянськості; попри відносне домінування впливу еліт, кожен пересічний громадянин може впливати на прийняття владних рішень завдяки децентралізації влади і децентрації ініціативи. Це важлива передумова створення сприятливих умов для формування особистісного потенціалу солідарності, а отже - досягнення і збереження суспільної єдності. У контексті нашого дослідження цікавим видається виявлення співвідношення між зазначеними типами ініціатив, оскільки вони $є$ механізмом підтримання соціальної солідарності, а також значною мірою пов'язані з іншими механізмами солідарності.

Більше того, досягнення оптимального балансу ініціативи в суспільстві важливе для збереження цілісності соціального полотна i створення передумов виникнення сприятливої ситуації суспільного розвитку. Небезпеку, відповідно, становить нав'язування, диктування «правил гри» зверху вниз, що перетворює суспільство в тоталітарне, авторитарне, інтенсифікуючи конформістські процеси на внутрішньоособистісному, міжсуб'єктному і міжгруповому рівнях. Для суспільства гармонійнішими $є$ зміни «знизу», коли вони органічно визрівають усередині суспільства. Це запорука сталості таких змін. Два основні компоненти, які визначають готовність і спроможність суспільства до змін «знизу», це: частка людей, які здійснюють суб'єктні соціальні дії (вчинки); культурні рамки (цінності) суб'єктних та агентних дій.

Процеси солідаризації, окрім балансу ініціатив, потребують також збалансування процесів конкурування і кооперування спільнот, що може бути лише відносним і потребує постійних зусиль учасників соціальної 
взаємодії, полілогу, який здійснюється динамічно й значною мірою залежить від ряду чинників. У суспільному організмі важлива взаємодія різних його елементів. Ключ до успішного функціонування цього організму потрібно шукати в переосмисленні цієї взаємодії. Це знову актуалізує й потребу переосмислення впливу готовності брати особистісну відповідальність за стан суспільства і доводить також актуальність проблеми соціальної відповідальності не лише в процесі особистісної зрілості, а й у межах розвитку суспільства як групи співвідповідальних і співвільних його суб'єктів. Адже загальна рамка взаємодій сьогодні потребує переходу з логіки «гри 3 нульовою сумою» до позитивної логіки співпраці («win-win»). Це така взаємодія, коли кожен шукає компромісні і взаємовигідні рішення для себе та інших. Важливо розуміти, що свобода дій має бути позитивною - взаємодія, у якій кожен може діяти вільно, але за умови, що це не порушує прав та свобод інших.

«Інгредієнтом», який остаточно перетворить суспільство на цілісне (партнерське), а не фрагментоване (конкурентне), $є$ спроможність об'єднуватись. Щоб уможливити взаємодію в логіці «win-win» i позитивну свободу, потрібно навчитися слухати одне одного та вести діалог (полілог). Саме тому як психологічна основа соціальних відносин така важлива довіра, зокрема здатність давати кредит довіри - це найважчий крок для активізації позитивних змін у суспільстві. Взаємодія солідаризованого суспільства разом з тим передбачає вміння вести діалог (із владою, з колегами, сусідами) через консенсус і партнерство, а не конкуренцію. У цьому річищі громадянське суспільство може стати «критичною масою», яка формуватиме запит на нові правила гри в рамках описаної вище взаємодії, посилюватиме його через поширення успішних прикладів того, як «по-іншому» можна досягати успіху.

$\mathrm{У}$ сучасному науковому дискурсі комунікацію розглядають як процес, як спосіб і як механізм, за допомогою якого забезпечується існування та розвиток людських відносин. Комунікація постає як інтегрований процес, у якому поєднуються різні аспекти і функції, зокрема: комунікація як трансмісія (лінійна трансляція, передавання інформації, ідей, емоцій, умінь); комунікація як засіб порозуміння 3 іншими; комунікація як вплив і взаємовплив; комунікація як об'єднання (творення спільноти); комунікація як взаємодія; комунікація як обмін; комунікація як складова суспільного процесу, який виражає групові норми, здійснює громадський контроль, розподіляє ролі, забезпечує координацію зусиль. За такої умови в інтернетизованому суспільстві всесвітня мережа $є$ водночас i засобом комунікації, i простором комунікативної взаємодії, і середовищем, у якому суб’єкти реалізують 
комунікативні практики. Разом з усталеними соціальними комунікативними практиками новоутворені інтернет-практики впливають на спосіб мислення, структуру ціннісних пріоритетів людини, процес ії самовизначення. Результати аналізу дослідницьких джерел показують, що в умовах нової суспільної реальності, незалежно від режиму спілкування, iї вимірів та цілей, застосовуються різні типи комунікативних практик: активно-конструктивні, реактивно-конструктивні, активно-деструктивні і реактивно-деструктивні; комунікативні практики розгортаються i трансформуються в діалогах та полілогах. Полілог у соціальному просторі інтегрує висловлювання думки декількох його учасників. Саме для полілогу часто характерний прояв деструктивних i реактивнодеструктивних комунікативних практик (образи, провокації, розпалювання конфліктів, хамство, соціальна агресія, протистояння). На рівні соціального функціонування полілог є водночас і процесом спілкування, i формою взаємодії. Від того, які комунікативні практики використовують учасники спілкування / соціальної взаємодії, залежить конструктивність полілогу і характер їхньої взаємодії в майбутньому.

Оскільки спільнота $є$ великою групою, тому уявно-опосередковані та умовно-символічні контакти, притаманні ій, стосуються і великих груп. Такі види контактів (досить інтенсивні та ефективні) можуть реалізуватись у різних формах комунікації, зокрема у формі полілогу. На це впливає, зокрема, притаманне сучасному соціуму явище множинності великих соціальних груп, які функціонують одночасно, і множинність ідентичностей (одні і ті ж люди одночасно належать до різних груп). Описані суспільні умови (трансформаційні) зумовлюють потребу взаємодіяти (солідаризуватись/десолідаризуватись, телорувати/конфліктувати тощо) досить динамічно. Тому полілог - це один із дієвих і досить ефективних механізмів соціальної взаємодії. У цьому контексті відносно новою вважається техніка модерації, що сприяє суб'єкт-суб'єктній взаємодії учасників полілогу, дає змогу створювати психологічно комфортні умови соціальної інтеракції. Цілеспрямовані дії модератора (іншої групи-, суспільства- чи особи-посередника) створюють сприятливі умови для розгортання конструктивних, консолідаційних комунікативних практик i блокування деструктивних (конфронтаційних, агресивних). Зауважимо, що положення соціально-психологічної теорії ролей виявилися досить продуктивними в дослідженні нами полілогу як механізму соціальної солідарності. Варто зазначити, що під час діалогічної взаємодії інтеракції утворюють діалогічний простір полілогу. В. Гордієнко (2008; 2009) зауважує, що «в умовах інтенсивного зворотного зв'язку спілкування закономірно когнітивізується» і діалоги, як проєктована комунікація, сприяють розумінню людей. 
Чинниками сучасних ідентифікаційних процесів в українському суспільстві є: нестабільність, що зумовила пріоритет адаптивнозахисного характеру особистісної ідентифікації; порушення домінуючої системи соціальної регуляції і відповідних матриць соціальної поведінки, які спровокували зміни в структурі ідентифікаційної ієрархії і механізмах соціальної самоідентифікації особистості; розпад соціальної системи загалом, як наслідок - розвиток різноманітних форм i стилів, маргіналізація значної частини населення, гетерогенність «офіційних» соціальних груп. Пошук першочергових завдань i можливостей їх вирішення в умовах соціальної ситуації, на наше переконання, має фокусуватися на базових засадах соціальності. Вони ж пов'язані 3 первинними потребами, що лежать в основі солідарності зокрема. А це насамперед співпричетність і співдія як базові психологічні механізми соціального здоров'я. Такий механізм буває ефективним, тільки коли він активізує одночасно два канали: співроздумування і співчуття (емпатію), оскільки соціальні зв'язки відбувається в річищі спілкування і взаємодії на основі довіри. А проте в такій взаємодії потрібно звернути увагу на поняття «емпатійна співпричетність», що означає участь у дії через механізм узгодження соціальних очікувань партнерів, завдяки чому відбувається взаємне проникнення («зчеплення») емоційних і раціональних компонентів соціальних суб'єктів. Тому співпричетність можна вважати найбільш цінним елементом соціальної взаємодії, який передбачає перехід від співчуття, доброзичливості, акцептації до співдії для того, щоб сприяти більш повному залученню можливостей членів групи, соціуму в так звану «стадію активності» солідарності. Як відомо, така взаємодія має інваріантну структуру, де виділяються орієнтувальний, виконавчий і контрольний компоненти, які є більш простими діями.

Отже, соціальна взаємодія виглядає як інтегральна, оскільки містить у собі і динамічну суб'єктну позицію соціальних ії суб'єктів у процесі адаптації до соціальної реальності (принцип картографічності). Механізм співпричетності забезпечує таким чином реалізацію потреби бути разом, відчувати потрібність, схожість, важливість, прийняття тощо. У контексті суспільних відносин такий механізм сприяє запобіганню маргіналізації як процесу зростання чисельності та посилення впливу маргінальних груп у суспільстві, найхарактернішою ознакою чого $\epsilon$ «відсування» на периферію або за межі суспільства загалом, або ж за межі окремих його груп. Саме тому співпричетність сприяє підвищенню ефективності соціальної взаємодії, зміцненню відносин, зрештою солідаризації. За таких умов відбувається формування почуття цінності інших, прагнення розуміти їх. Саме відчуття співпричетності може 
заповнити ту нішу, що активізуватиме солідаризацію як інтеграційну основу суспільства.

Висновки та перспективи подальших досліджень. Отже, соціальна солідарність як специфічна властивість суспільства виникає стихійно або керовано на основі інтеграції особистісних потенціалів солідарності більшості його членів, завдяки чому відбувається конвергенція суспільних процесів (соціальних, політичних, психологічних, освітніх, інформаційних тощо) на спільній меті та формується згуртованість на рівні великих груп. Солідарність як згуртованість великих груп уможливлює ефективне розв'язання проблем i досягнення цілей сталого розвитку. Потреба в новому погляді на поняття і механізми солідарності пов'язана 3 тим, що багато феноменів сучасних солідаризаційних процесів сьогодні неможливо пояснити тільки на засадах класичних теорій солідарності. Загальноприйнятим стає поняття «нова солідарність», яке поступово втрачає територіальну, класову заангажованість, уже більше не відтворює постійну спільність інтересів, цінностей. Солідаризація набуває характеристик різновимірності (від цивілізаційного до міжособистісного), які тісно взаємопов'язані 3 інтенсивністю, типами, механізмами зв'язків між соціальними суб'єктами, характером і способом комунікації, особливостями ідентифікаційних процесів, що відкриває нові горизонти соціальнопсихологічних досліджень. Психологічне структурування соціальної солідарності уможливлює розмежування іiі особливостей на різних соціальних вимірах. А акцентування уваги на соціальній взаємодії, комунікації, ролі довіри, соціальної відповідальності і толерантності в процесах солідаризації розкриває специфіку різновекторної площини досягнення і збереження соціальної солідарності й спрямованості впливу під час взаємодії. Особистість, як член певної сукупності великих груп, одночасно перебуває на перетині багатьох впливів, унаслідок чого формує своє усвідомлене ставлення до певних перспектив суспільного життя. Психологічним осередком такого ставлення $\epsilon$ «особистісний потенціал солідарності» як система індивідуальних відмінностей, пов'язана 3 інтенціями на згуртованість навколо певних смислів, цілей і цінностей.

Солідарність як згуртованість великих соціальних груп досягається завдяки дії низки механізмів, зокрема переживання співпричетності, полілогу спільнот, висхідної та низхідної ініціативи і динамічного балансу процесів конкурування і кооперування спільнот. Під соціальним механізмом досягнення та підтримання соціальної солідарності мається на увазі стійка система взаємодій великих соціальних груп різних типів $\mathrm{i}$ рівнів, що сприяє виробленню спільноподілюваної мети (перспектив i векторів суспільного руху). Функціонування соціальних механізмів, 
здатних регулювати процеси досягання та підтримання солідарності, регулюється відповідними громадськими інститутами і соціальним статусом та особливостями великих груп. Така здатність пояснюється особливою значущістю, силою і стійкістю тих соціальних зв'язків, які зумовлюють їхню системність. До того ж ці механізми відрізняються високою інерційністю і їхнє оновлення завжди $є$ лише частковим; у них співіснують феномени і цілеспрямовано створювані для досягнення певних цілей (конституюються в процесі соціальних перетворень), і ті, що виникають стихійним або природно-історичним шляхом (виникають спонтанно в процесі суспільної еволюції і змінюються під впливом внутрішніх трансформацій).

Здійснений міждисциплінарний аналіз соціальної солідарності, вивчення ії соціально-психологічної структуризації, акцентування уваги на сучасних підходах і перспективах іiі розроблення в межах соціальної психології в умовах поглиблення соціальної диференціації і трансформаційних змін суспільства розкривають перспективи подальших досліджень у напрямі з'ясування сутності особистісного потенціалу солідарності та чинників його формування, а також можливостей досягнення соціальної солідарності на різних вимірах соціуму.

\section{Список використаних джерел}

Бауман, 3. (2002). Индивидуализированное общество. Москва: Логос.

Бек, У. (2000). Общество риска. На пути к другому модерну. Пер. с нем. В. Седельника и Н. Федоровой; Послесл. А. Филиппова. Москва: ПрогрессТрадиция.

Богомолова, Н. Н. (2002). Психология больших социальных групп: новые судьбы, новые подходы. В Н. Н. Богомолова, А. И. Донцов, Т. В. Фоломеева, Социальная психология в современном мире (с. 132-147). Москва: Аспект Пресс.

Васютинський, В. (2010). Психологічні виміри спільноти. Київ: Золоті ворота. Взято $3 \mathrm{http}: / /$ www.ispp.org.ua/backup_ispp/1426077022.pdf

Габермас, Ю. (2000). Структурні перетворення у сфері відкритості: дослідження категорії громадянське суспільство. Львів: Літопис.

Гидденс, Э. (2004). Трансформация интимности. Санкт-Петербург: Питер.

Гордієнко, В. І. (2008). Проблема діалогу в умовах реалій «психологічного суспільства». Наукові записки НаУКМА. Психологічні, педагогічні науки та соиіальна робота, Т. 84, 38-45.

Гордієнко, В. І. (2009). Моделі комунікативного процесу в сучасній психології та їхній потенціал у поясненні діалогічності спілкування. Наукові записки НАУКМА. Психологічні, педагогічні науки та сойіальна робота, Т. 97, $55-60$. 
Духневич, В. М. (2013). Принципи забезпечення та організації діалогічної взаємодії. Актуальні проблеми психології. Збірник наукових праџьь Інституту психології імені Г. С. Костюка НАПН України. Т. 7. Екологічна психологія. Вип. 34. Взято з http://appsychology.org.ua/data/jrn/v7/i34/11.pdf

Слюсаревський, М. М., Найдьонова, Л. А., Титаренко, Т. М., Татенко, В. О., Горностай, П. П., Кочубейник, О. М., \& Лазоренко, Б. П. (2020). Життевий світ $і$ психологічна безпека людини в умовах суспільних змін. Реферативний опис роботи. Київ: Талком. Взято 3 http://gorn.kiev.ua/DerjPremia2019.pdf

Лобанова, А. С., \& Коломоєць, Т. Г. (2016). Солідаризація професійних відносин у сфері праці в умовах суспільних викликів. Ринок праиі та зайнятість населення, 1(46), 51-55. Взято 3 https://ipk.edu.ua/wp-content/uploads/2019/09/120161.pdf

Овчаров, А. О. (2011). Механізми інтеграції-диференціації як соціальнопсихологічні фактори еволюції ідеологій. Проблеми політичної психологіï, 11, $149-153$.

Орбан-Лембрик, Л. Е. (2004). Соціальна психологія: підручник: у 2 кн. Кн. 1: Соціальна психологія особистості і спілкування. Київ: Либідь.

Рорти, Р. (1996). Случайность, ирония и солидарность. Пер. с англ. И. Хестановой, Р. Хестанова. Москва: Русское феноменологическое общество.

Сіверс, 3. Ф. (Ред.), Духневич, В. М., \& Осадько, О. Ю. (2017). Прикладні аспекти становлення політико-правової свідомості молоді. Кропивницький: Імекс-ЛТД. Взято 3 http://psy-lpr.at.ua/Materials/SiversPosib2017.pdf

Суший, О. В. (2018). Соціальна психологія націєтворення: концептуальні засади і методологічні принципи дослідження. Наукові студї із соціальної та політичної психології, 41 (44), 3-19.

Татенко, В. О. (2020). Соціальна психологія націєтворення: суб’єктновчинковий пiдxiд. Кропивницький: Імекс-ЛТД.

Титаренко, Т. М., Кочубейник, О. М., \& Черемних, К. О. (2014). Психологічні практики конструювання життя в умовах постмодерної соиіальності. Київ: Міленіум.

Урри, Дж. (2012). Соииология за пределами обществ: виды мобильности для XXI столетия. Москва: Изд. дом Высшей школы экономики. Взято из https://id.hse.ru/data/2012/06/20/1255154102/\%D0\%A3\%D1\%80\%D1\%80\%D0\%B8.pdf

Фестингер, Л. (1999). Теория когнитивного диссонанса. Санкт-Петербург: Ювента.

Филиппов, А. Ф. (2008). Чувственность и мобилизащия. К проблеме политической эстезиологии. De Futuro, или История будущего. Москва: Политический класc, АИРО с. 134-156; 207-231. Взято из https://www.hse.ru/pubs/share/direct/content_document/176862125 
Amin, A. (2002). Ethnicity and the Multicultural City: Living with Diversity. Environment and Planning A: Economy and Space, 34 (6), 959-980. doi: https://doi.org/10.1068/a3537.

Brunkhorst, H. (2005). Solidarity From Civic Friendship to a Global Legal Community. Cambridge/London: MIT Press. Retrieved from https://www.researchgate.net/publication/262907398_Solidarity_From_Civic_Friendshi p_to_a_Global_Legal_Community_CambridgeLondon_MIT_Press_2005

Cheong, P. H., Edwards, R., Goulbourne, H. \& Solomos, J. (2007). Immigration, Social Cohesion and Social Capital: A Critical Review. Critical Social Policy, 27, 24-49. doi: https://doi.org/10.1177/0261018307072206

Davies, B., \& Savulescu, J. (2019). Solidarity and Responsibility in Health Care. Public Health Ethics, Vol. 12, No 2, 133-144. DOI: https://doi.org/10.1093/phe/phz008.

Gofman, A. (2019). Tradition, morality i solidarity в Durkheim's theory. Istanbul University Journal of Sociology, 39, 25-39. doi: https://doi.org/10.26650/SJ.2019.39.1.0007.

Larsen, C. A. (2013). The Rise and Fall of Social Cohesion: The Construction and Deconstruction of Social Trust in the US, UK, Sweden and Denmark. Oxford: OUP. doi: https://doi.org/10.1093/acprof:oso/9780199681846.001.0001

Savulescu, J. (2018). Golden Opportunity, Reasonable Risk and Personal Responsibility for Health. Journal of Medical Ethics, 44, 59-61. doi: https://doi.org/10.1136/medethics-2017-104428

Sellberg, M. M., Wilkinson, C., \& Peterson, G. D. (2015). Resilience Assessment: A Useful Approach to Navigate Urban Sustainability Challenges. Ecology and Society, 20 (1). doi: https://doi.org/10.5751/ES-07258-20014

Stjerno, S. (2004). Solidarity in Europe: The History of an Idea. Publisher: Cambridge University Press. DOI: https://doi.org/10.1017/CBO9780511490378

Tajfel, H. (1979). Individuals and groups in social psychology. British Journal of Social and Clinical Psychology, 18 (2), 183-190. doi: https://doi.org/10.1111/j.20448260.1979.tb00324.x

Wellman, B. \& Wortley, S. (1990). Different Strokes from Different Folks: Community Ties and Social Support. American Journal of Sociology, 96, 558-588. doi: https://doi.org/10.1086/229572

Wilde, L. (2007). Solidarity in Europe: The History of an Idea. Contemp Polit Theory, 6, 117-119. doi: https://doi.org/10.1057/palgrave.cpt.9300271

\section{References}

Amin, A. (2002). Ethnicity and the Multicultural City: Living with Diversity. Environment and Planning A: Economy and Space, 34 (6), 959-980. doi: https://doi.org/10.1068/a3537 (in English)

Bauman, Z. (2002). Individualizirovannoye obshchestvo [Individualized society]. Moscow: Logos. (in Russian) 
Bek, U. (2000). Obshchestvo riska. Na puti k drugomu modern [Risk society. On the way to another modernity]. Moscow: Progress-Traditsiya. (in Russian)

Bogomolova, N. N. (2002). Psikhologiya bolshikh sotsialnykh grupp: novyye sudby, novyye podkhody [Psychology of large social groups: new destinies, new approaches]. In N. N. Bogomolova, A. I. Dontsov, T. V. Folomeyeva, Sotsialnaya psikhologiya v sovremennom mire [Social psychology in the modern world]. Moscow: Aspekt Press, p. 132-147. (in Russian)

Brunkhorst, H. (2005). Solidarity From Civic Friendship to a Global Legal Community. Cambridge/London: MIT Press Retrieved from https://www.researchgate.net/publication/262907398_Solidarity_From_Civic_Friendshi p_to_a_Global_Legal_Community_CambridgeLondon_MIT_Press_2005 (in English)

Cheong, P. H., Edwards, R., Goulbourne, H., \& Solomos, J. (2007). Immigration, Social Cohesion and Social Capital: A Critical Review. Critical Social Policy, 27, 24-49. doi: https://doi.org/10.1177/0261018307072206 (in English)

Davies, B., \& Savulescu, J. (2019). Solidarity and Responsibility in Health Care. Public Health Ethics, Vol. 12, No 2, 133-144. doi: https://doi.org/10.1093/phe/phz008. (in English)

Dukhnevych, V. M. (2013). Pryntsypy zabezpechennia ta orhanizatsii dialohichnoi vzaiemodii [Principles of providing and organizing dialogic interaction]. Aktualni problemy psykholohii. Zbirnyk naukovykh prats Instytutu psykholohii imeni $H$. $S$. Kostyuka NAPN Ukrainy [Current problems of psychology. Collection of scientific works of the GS Kostyuk Institute of Psychology of the National Academy of Pedagogical Sciences of Ukraine]. Vol. 7. Ekolohichna psykholohiia. Is. 34. Retrieved from http://appsychology.org.ua/data/jrn/v7/i34/11.pdf (in Ukrainian)

Festinger, L. (1999). Teoriya kognitivnogo dissonansa [The theory of cognitive dissonance]. St. Petersburg: Yuventa. (in Russian)

Filippov, A. F. (2008). Chuvstvennost i mobilizatsiya. K probleme politicheskoy esteziologii. De Futuro, ili Istoriya budushchego [Sensuality and mobilization. On the problem of political aesthesiology. De Futuro, or History of the Future.]. Moscow: Politicheskiy klass, AIRO. Retrieved from https://www.hse.ru/pubs/share/direct/content_document/176862125 (in Russian)

Giddens. E. (2004). Transformatsiya intimnosti [Transformation of Intimacy]. St. Petersburg: Piter. (in Russian)

Gofman, A. (2019). Tradition, morality i solidarity в Durkheim's theory. Istanbul University Journal of Sociology, 39, 25-39. doi: https://doi.org/10.26650/SJ.2019.39.1.0007 (in English)

Habermas, Yu. (2000). Strukturni peretvorennia u sferi vidkrytosti: doslidzhennia katehorii hromadianske suspilstvo [Structural transformations in the field of openness: a study of the category of civil society]. Lviv: Litopys. (in Ukrainian)

Hordiienko, V. I. (2008). Problema dialohu v umovakh realii «psykholohichnoho suspilstva» [The problem of dialogue in the realities of «psychological society"]. Naukovi zapysky NaUKMA. Psykholohichni, pedahohichni 
nauky ta sotsial $\square$ na robota [Scientific notes of NaUKMA. Psychological, pedagogical sciences and social work], 84, 38-45. (in Ukrainian)

Hordiienko V. I. (2009). Modeli komunikatyvnoho protsesu v suchasnii psykholohii ta yikhnii potentsial u poiasnenni dialohichnosti spilkuvannia [Models of communicative process in modern psychology and their potential in explaining the dialogic nature of communication]. Naukovi zapysky NAUKMA. Psykholohichni, pedahohichni nauky ta sotsialna robota [Scientific notes of NAUKMA. Psychological, pedagogical sciences and social work], 97, 55-60. (in Ukrainian)

Larsen, C. A. (2013). The Rise and Fall of Social Cohesion: The Construction and Deconstruction of Social Trust in the US, UK, Sweden and Denmark. Oxford: OUP. doi: https://doi.org/10.1093/acprof:oso/9780199681846.001.0001 (in English)

Lobanova, A. S., \& Kolomoyets, T. H. (2016). Solidaryzatsiia profesiinykh vidnosyn u sferi pratsi $\mathrm{v}$ umovakh suspilnykh vyklykiv [Solidarity of professional relations in the field of work in the face of social challenges]. Rynok pratsi ta zaynyatist naselennia [Labor market and employment], 1(46), 51-55. Retrieved from https://ipk.edu.ua/wp-content/uploads/2019/09/1-20161.pdf (in Ukrainian)

Orban-Lembryk, L. E. (2004). Sotsialna psykholohiia: pidruchnyk: $u 2 \mathrm{kn}$. Kn. 1: Sotsialna psykholohiia osobystosti i spilkuvannia [Social psychology: textbook: in 2 books.]. Kyiv: Lybid. (in Ukrainian)

Ovcharov, A. O. (2011). Mekhanizmy intehratsii-dyferentsiatsii yak sotsial $\square$ no-psykholohichni faktory evolyutsii ideolohii [Mechanisms of integrationdifferentiation as socio-psychological factors of evolution of ideologies.]. Problemy politychnoi psykholohii, 11, 149-153. (in Ukrainian)

Rorti, R. (1996). Sluchaynost, ironiya i solidarnost. Randomness, Irony and Solidarity. Moscow: Russkoye fenomenologicheskoye obshchestvo. (in Russian)

Savulescu, J. (2018). Golden Opportunity, Reasonable Risk and Personal Responsibility for Health. Journal of Medical Ethics, 44, 59-61. doi: https://doi.org/10.1136/medethics-2017-104428 (in English)

Sellberg, M. M., Wilkinson, C., \& Peterson, G. D. (2015). Resilience Assessment: A Useful Approach to Navigate Urban Sustainability Challenges. Ecology and Society, 20 (1). doi: https://doi.org/10.5751/ES-07258-20014 (in English)

Sivers, Z. F. (Ed.), Dukhnevych, V. M., Osadko, O. Yu. (2017). Prykladni aspekty stanovlennia politykopravovoi svidomosti molodi [Applied aspects of the formation of political and legal consciousness of youth]. Kropyvnytskyi: Imeks-LTD. Retrieved from http://psy-lpr.at.ua/Materials/SiversPosib2017.pdf (in Ukrainian)

Stjerno, S. (2004). Solidarity in Europe: The History of an Idea. Publisher: Cambridge University Press. doi: https://doi.org/10.1017/CBO9780511490378 (in English)

Sushyy, O. V. (2018). Sotsialna psykholohiia natsiietvorennia: kontseptualni zasady i metodolohichni pryntsypy doslidzhennia [Social psychology of nationbuilding: conceptual principles and methodological principles of research.]. Naukovi studii iz sotsialnoi ta politychnoi psykholohii [Scientific studies in social and political psychology], 41 (44). 3-19. (in Ukrainian) 
Tajfel, H. (1979). Individuals and groups in social psychology. British Journal of Social and Clinical Psychology, 18 (2), 183-190. doi: https://doi.org/10.1111/j.20448260.1979.tb00324.x (in English)

Tatenko, V. O. (2020). Sotsialna psykholohiia natsiietvorennia: subiektnovchynkovyi pidkhid [Social psychology of nation-building: subject-action approach]. Kropyvnytskyi: Imeks-LTD (in Ukrainian)

Tytarenko, T. M., Kochubeynyk, O. M., Cheremnykh, K. O. (2014). Psykholohichni praktyky konstruiuvannia zhyttia v umovakh postmodernoi sotsialnosti [Psychological practices of constructing life in postmodern society]. Kyiv: Milenium. Retrieved from http://www.ispp.org.ua/backup_ispp/1423061573.pdf (in Ukrainian)

Urri, J. (2012). Sotsiologiya za predelami obshchestv: vidy mobilnosti dlya XXI stoletiya [Sociology Beyond Societies: Types of Mobility for the 21st Century]. Moscow: Izd. dom Vysshey shkoly ekonomiki. Retrieved from https://id.hse.ru/data/2012/06/20/1255154102/\%D0\%A3\%D1\%80\%D1\%80\%D0\%B8. pdf (in Russian)

Vasiutynskyi, V. (2010). Psykholohichni vymiry spilnoty [Psychological dimensions of community]. Kyiv: Zoloti vorota. (in Ukrainian)

Wellman, B. \& Wortley, S. (1990). Different Strokes from Different Folks: Community Ties and Social Support. American Journal of Sociology, 96, 558-588. doi: https://doi.org/10.1086/229572 (in English)

Wilde, L. (2007). Solidarity in Europe: The History of an Idea. Contemp Polit Theory, 6, 117-119. doi: https://doi.org/10.1057/palgrave.cpt.9300271 (in English)

Slyusarevskyy, M. M., Naydonova, L. A., Tytarenko, T. M., Tatenko, V. O., Hornostay, P. P., Kochubeynyk, O. M., \& Lazorenko, B. P. (2020). Zhyttievyi svit $i$ psykholohichna bezpeka liudyny $v$ umovakh suspilnykh zmin. Referatyvnyi opys roboty [The world of life and psychological security of the person in the conditions of social changes]. Kyiv: Talkom. Retrieved from http://gorn.kiev.ua/DerjPremia2019.pdf (in Ukrainian) 